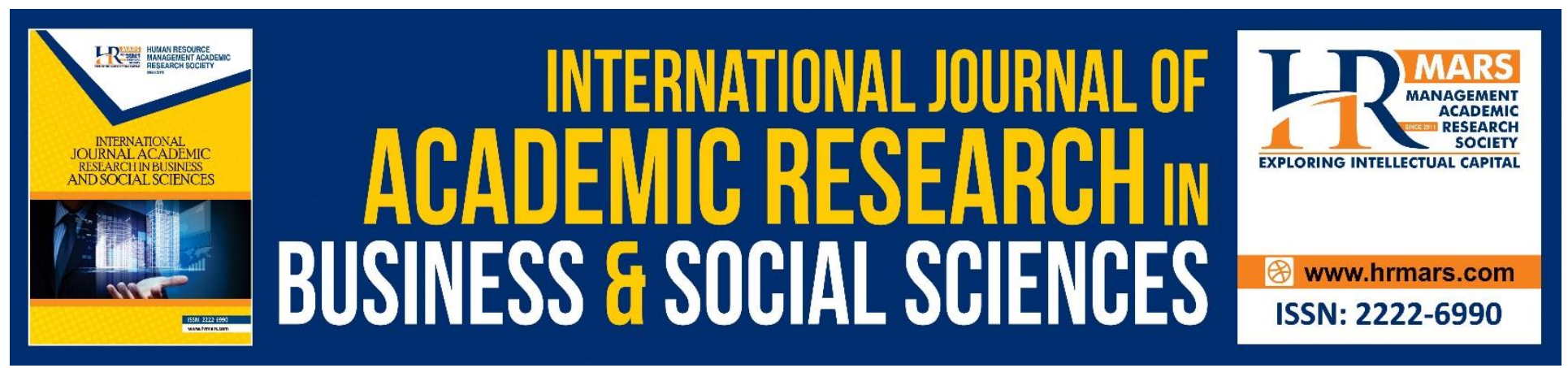

\title{
Christianity and Widowhood Rites in Africa: An Audit of The Effects of Ababukusu Indigenous Culture on Widows in The Context of Friends Church in Western Kenya
}

Dinah Nakhungu Wekesa and Ochieng Lukes Ahaya

To Link this Article: http://dx.doi.org/10.6007/IJARBSS/v10-i10/7925

DOI:10.6007/IJARBSS/v10-i10/7925

Received: 27 July 2020, Revised: 21 August 2020, Accepted: 19 September 2020

Published Online: 15 October 2020

In-Text Citation: (Wekesa, and Ahaya, 2020)

To Cite this Article: Wekesa, D. N., and Ahaya, O. L. (2020). Christianity and Widowhood Rites in Africa: An Audit of The Effects of Ababukusu Indigenous Culture on Widows in The Context of Friends Church in Western Kenya .International Journal of Academic Research in Business and Social Sciences. 10(10), 182-190.

\section{Copyright: (C) 2020 The Author(s)}

Published by Human Resource Management Academic Research Society (www.hrmars.com)

This article is published under the Creative Commons Attribution (CC BY 4.0) license. Anyone may reproduce, distribute, translate and create derivative works of this article (for both commercial and non-commercial purposes), subject to full attribution to the original publication and authors. The full terms of this license may be seen

at: $\underline{\text { http://creativecommons.org/licences/by/4.0/legalcode }}$

Vol. 10, No. 10, 2020, Pg. 182 - 190

Full Terms \& Conditions of access and use can be found at http://hrmars.com/index.php/pages/detail/publication-ethics 


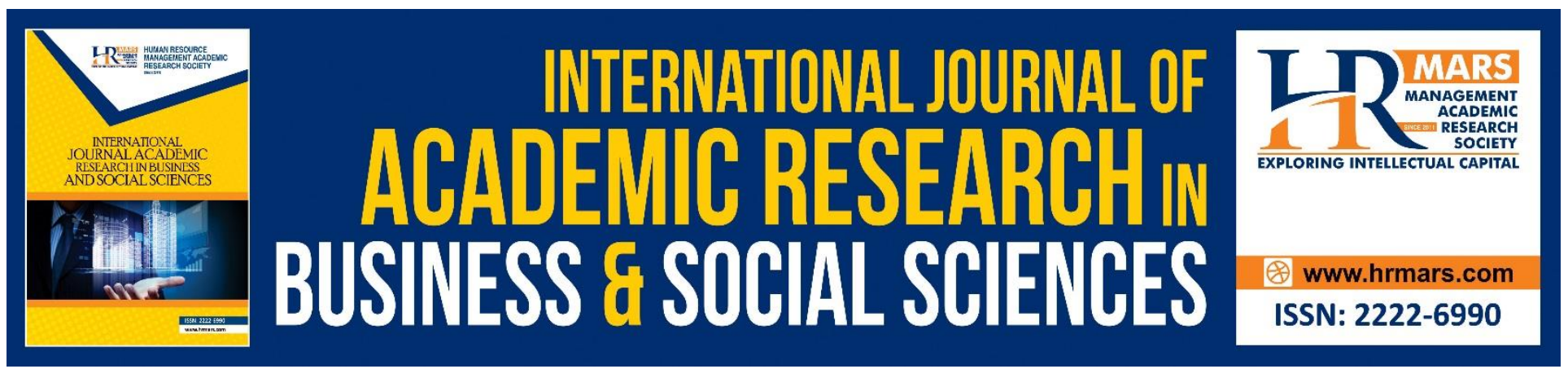

\title{
Christianity and Widowhood Rites in Africa: An Audit of The Effects of Ababukusu Indigenous Culture on Widows in The Context of Friends Church in Western Kenya
}

\author{
Dinah Nakhungu Wekesa and Ochieng Lukes Ahaya \\ Masinde Muliro University, Kakamega
}

\begin{abstract}
Religion, life and death are entwined and the knowledge of one requires the knowledge of the other. Religions have addressed the question of how one should live with awareness of inevitability of death. Consequently, societies have developed systems of belief and practice to help their people cope with the prospect of death and the attendant sorrow and grief. Drawing interest from the complex intertwine surrounding death and religion, the main problem addressed by the study was to examine the extent to which the Interplay between the Ababukusu traditional, and Friends Church cultures with regard to widowhood rituals had subjugated the widows. The study was guided by structural functionalism by Emile Durkheim (1858 - 1917) and Herbert Spencer (1820 - 1903) and how it functioned abnormally from a gender perspective. Structural functionalism theory informed the study that the rites and rituals performed after death of husband enhanced solidarity and stability of the society, yet this was at the expense of the female gender. This study found out that the Ababukusu widowhood rites and rituals repositioned widows in society in ways that were generally depriving as the Friends Church watched and even supported tacitly. The study advises in this regard that the widowhood rites and rituals should not be abandoned completely, but instead be infused deliberately with humane values as befits ubuntu and biblical teaching of love and care with regard to widowhood.
\end{abstract}

Keywords: Rituals, Beliefs, Death, Christianity, Tradition.

\section{Introduction}

Religion has been perceived variously by different scholars. To some like Mawson (2005) religion seem to have its roots in the prevalence of the puzzlement with the physical world throughout time and across cultures that equally explains the persistence of the philosophy of religion and metaphysical thinking. This puzzlement is the one Schopenhauer (2010) once referred to as, 'the pendulum which keeps the clock of metaphysics in motion.' From this perspective religion is conceived as those systems of thought that view physicalism (that the physical world is on its own and by itself) as false, and that claim then that there is something 
outside the physical world that accounts for the world. This position holds that there is something beyond the world that natural sciences describe and that, that something explains why there is a world for us to deliberate on, and why there is an us, to do the deliberation. Consequently, the physical world as a whole continues to strike us in our reflective moments as it did then, as a question to which an answer is required and yet the answer is sadly elusive. This perspective to understanding religion is the one often echoed by the social scientists when they view religion as the attempt to answer the more crucial existential questions, such as; 'is there life after death?' and 'how does the universe work and what's our role in it?' This approach to religion highlights its functional role as serving specific social ends.

The religious view as a response to the physicalism puzzle has always been more popular. One ancient writer once summed up his observations about the nature of world cultures: 'one can find cities without kings; without walls; and without coinage, but there has never been found a city without gods.' The religious view, as provided by the physical world, recognizes the truth of this question. This view accepts the fact that the physical world is a question that requires an answer. Specifically, the followers of each religion whether African Religion or Christianity claim that their religion provides the answer to this question. It is however at the juncture of what sort of thing the various religions of the world say this answer is that we come to the great divide among the world's religions.

Scientists and poets have for a long time recognized that life, death and religion as part of the puzzlement of the physical world are so intimately entwined that knowledge of one requires knowledge of the other. Religions have been addressing the question of how to live with the knowledge of inevitable death for a long time. The history of death as a phenomenon is definitely long and with mythical overlaps. Kastenbaum (2003) in an attempt at a historical documentation of death in what he calls the 'history of darkness,' brings us closer in time to this phenomenon. As far as death is concerned, he observes that the twenty-first century inherited from the past an anxiety closet filled with collective memories of disturbing experiences. This history when analyzed critically conceals threats from predators and enemies; Kastenbaum cites cases of child-bearing women and their young children who suddenly turn pale and die and terrible plagues that periodically ravage the populations. In some instances, it would appear that the dead themselves are sources of terror when resentful of the living. The fear surrounding death in many cases implied that though contact with corpses was inevitable, this had to be managed with diligence, lest the departing spirit be offended. This history also indicates that the spirit world often intervened in everyday lives including death moments, and gods, demi-gods and aggrieved or truculent ancestors had to be pacified by gifts, ceremonies, and conformity to their wishes. Animal and human sacrifices are equally common in relation to death, and were intended to protect the lives of the community by preventing catastrophes or assuring good crops. Everyday life is permeated as a result of death, by rituals designed to confuse or reward the religious forces that governed life and death.

'The history of darkness' as espoused by Kastenbaum, is related here at length because it helps us understand how all of these past encounters and more have bequeathed anxieties with regard to death that still influence attitudes toward death today. In this regard, Manning (1884) affirmed that knowledge of death is a fundamental human condition that gives meaning to life. All cultures have their own death-related customs and beliefs and each community has its own approach to dealing with the loss. Most of the rituals have their basis in people's traditional and religious systems. This idea is supported by Mbiti (1969) and Opoku (1978) who asserts that the African concept of death 
INTERNATIONAL JOURNAL OF ACADEMIC RESEARCH IN BUSINESS AND SOCIAL SCIENCES Vol. 10, No. 10, 2020, E-ISSN: 2222-6990 @ 2020 HRMARS

and rituals are closely linked to and influenced by traditional religion. In general pain, grief and sorrow typically color the thinking of the one dying as well as those closest to them in many African cultures. Death is surrounded with mystery, is cloaked in darkness, and is surrounded by fear and apprehension (Tibeba, 1997:19). The reaction of the primitive man to death has been terror. Man in Africa still responds with fear to death in this enlightened age. Death remains unknown. Clearly no one has ever died and came back to tell us what death really was like. Obviously, man hates what he cannot understand and command, so we can never fully understand death (Bayly, 1978:241). The death of the husband in most African communities impacts negatively on widows. Though death is a mystery to all according to Tibeba (1997), widows become extremely vulnerable upon their husband's death with the lives of many being turned into a living hell not just by in laws, but also by the society in general (Tibeba, 1997:126-137). This is not only due to traditional African culture but also due to the interplay between Christianity and the later despite Christianity's supposedly message of love. This results into emotional economic and social sufferings on the part of the widows. In many African communities, upon the death of a husband a widow is expected to keenly observe and adhere to all rituals before and after the burial of the husband which include the shaving of the hair, exoneration from suspicion and slaughtering of animals (Mbiti 1969:153).

Almost all world societies whether Christian or traditional African are male dominated. Such societies are structured such that women are bound by convention to fulfill certain roles and obligations. A mother for example is usually the wife with a duty of rising and looking after their children hence basically primary care givers, as the father is the head of the family. This division of roles in the family that put man at an advantageous position as the head of family is also at play with reference to funeral rituals and is not without ramifications on the general standings of widows in the society. This division of roles that subjects women to limitations has increasingly been called into question with both feminist and masculinist authors decrying such predetermined roles as unjust.

\section{Of Widowhood and Misery: The Statement of Problem}

The systemic consideration women in general merit has yet to be extended to death-related issues. For instance, widowhood is a prime example of misery and injustice in the wake of death in third world nations. Manala (2015) has raised concerns with these widowhood rites and rituals in relations to the resultant interplay between traditional African culture and Christian positions. Manala noted that while traditional African positions teach ubuntu values of family, mutual respect, compassion, and so on, they often don't speak about widows' care. On the other hand, Christian cultures preach unconditional love in the footsteps of Jesus of Nazareth, especially for the poor, oppressed and helpless, yet there is a significant lack of action with regard to the care of widows. There is thus, a deceptive contract in the form of unjust treatment of widows in African societies, despite the given ubuntu ideals and Christian teaching which emphasize love and caring, particularly for the grieving and therefore vulnerable widows. As a result, Widows in the present era tend to be ignored and even marginalized.

The missionaries introduced Christianity in Africa on denominational lines in the early $19^{\text {th }}$ century. In western Kenya, Friends church was established among the Ababukusu people. Prior to this, the Ababukusu had their indigenous religion and culture that outlined and guided them on the rituals that were to be performed after the death of a husband. It is due to the foregoing that the main concern of this study was to examine the interface between the Ababukusu traditional and the Friends Church widowhood rites and rituals with special reference to the subjugation to which they 
INTERNATIONAL JOURNAL OF ACADEMIC RESEARCH IN BUSINESS AND SOCIAL SCIENCES Vol. 10, No. 10, 2020, E-ISSN: 2222-6990 @ 2020 HRMARS

subjected Ababukusu African widows. To this end the study posited; to what extent had the combined Interplay between the Ababukusu cultural and Friends church widowhood rites and rituals subjugated the widow in Western Kenya.

\section{Theoretical Framework}

This study was based on a critical perception of the structural functionalism (a combination of contributions of Emile Durkheim 1858 - 1917 and Herbert Spencer (1820-1903) as it functions anomalously from a feminist perspective that explains the resultant subjugation of women in society. Functionalism as theory in application views society as a complex system whose parts function together to foster unity and stability. This theory states that religion and society are inseparable, and that religion exists in society because it functions. Durkheim in this way saw religion as a reflection of the concern for the society. He strongly emphasized that all religions are never just a matter of beliefs, but also constituted regular ceremonial and ritual activities in which a group of believers met together. In collective ceremonies, a sense of group solidarity is affirmed at a time when people are forced to adjust to major changes in their lives. Durkheim argued that rituals separated the spiritual from the natural, but enhanced key values in doing so.

Herbert Spencer (1820-1903) embraced the philosophy of functionalism by Emile Durkheim, who looked at society as a whole in terms of the roles of its constituent elements, namely norms, practices, rituals and institutions. Spencer described these parts of society as organs working towards the body as a whole's proper functioning. He referred to the metaphor of a human body just as the structural parts of the human body, the skull, the muscles and various internal organs worked individually to help the whole body survive, social structures worked together to sustain society. Structural functionalism attempts to explain the nature of social order and the relationship between the different parts (structures) of society by analyzing each individual part's functionality to assess how it contributes to the general stability of the society as a whole.

Gender inequality, while supposed to lead to stability in society according structural functionalism scheme, is bad for society in general and women in particular because it prevents women from reaching their potential. Because of their biological role in pregnancy and breastfeeding, women are primarily responsible for child care in nearly every culture and society around the world, limiting them to the domestic sphere as the more lucrative public sphere becomes a preserve for men. It is the perspective of this paper that as structural functionalism theory functions in society to create stability it also creates inequality at the same time and this is not normal. This abnormal functioning of structural functionalism was relevant to this study because death rituals as culturally assigned social roles among the Ababukusu are supposed to contribute to stable social relations, yet anomalous functioning of the theory sees the death rituals contribute instead to neglecting of the suppression of women within the family as is the argument from the feminist perspective. The gendering of death rituals as a result of social construction from the combined interplay between Ababukusu traditional and Friends church cultural positions was subjected to scrutiny from structural functionalist and feminist perspectives to establish the relationship with gender inequality among the Ababukusu people.

\section{Study Population and Sampling Technique}

The target population of this study was the Lugulu Friends Church yearly meeting in western Kenya with its 526 villages that constituted of 162 monthly meetings. From these, stratified random 
INTERNATIONAL JOURNAL OF ACADEMIC RESEARCH IN BUSINESS AND SOCIAL SCIENCES Vol. 10, No. 10, 2020, E-ISSN: 2222-6990 @ 2020 HRMARS

sampling was employed to obtain a sample of 162 women leaders and 162 pastors 12 of whom were women. Deliberate sampling was used to select 12 Ababukusu elders that included 6 males, 6 females 3 of whom were widows. These elders constituted the key informants for this study. Focus group discussion was finally employed to ventilate on the emerging issues for clarity. The focus group discussion constituted of 5 monthly meeting pastors, 5 women leaders from the monthly meeting, 6 elders 3 of whom were females and 2 yearly meetings pastors making a total of 18 discussants selected through stratified random sampling from various groups constituted in this study as already mentioned above.

\section{The Main Discussion}

This study had at its inception noted that the physical world as a whole continued to strike us in our reflective moments, as a question to which an answer was required and yet the answer was sadly elusive. It was also clear that for a long time, Religions have addressed the question of how one should live with the awareness of inevitable death. The study had also noted that death was characterized by a series of cultural rituals and rites of passage which at times continued as the living dead were remembered and continued to influence the actions of the living as is seen in the death of the husband in most African communities; a phenomenon that impacted negatively on widows. Though death was a mystery to all, widows in particular become extremely vulnerable upon their husbands' death with the lives of many turned upside down by both in laws and the society in general. The study postulated that this was not only due to traditional African culture but also due to an interface (a working together) between Christianity and the former despite Christianity's supposedly message of love and the traditional African teaching of ubuntu principles of communality, mutual respect, caring and so forth. There thus seemed to be a dishonest pact in the form of an apparent deliberate uncaring, disrespectful, discriminatory, impolite and unjust treatment of widows in African communities in spite of the confluence between ubuntu values and Christian teaching that emphasize love and caring, especially towards the grieving and thus vulnerable widows.

The position of indigenous Ababukusu and Christian Church working together could be observed in this study. For example, among the Ababukusu Friends Christians when death occurred, apart from funeral liturgical and committal services for the departed Christians at the church and the graveyard respectively, the Christian funeral observance was largely informed by the Ababukusu indigenous beliefs of the people. We can therefore argue that African funeral practices have extensively influenced Christian funeral ceremonies among the Ababukusu Christians. The Christian churches recognition of their members as having a dual identity to the traditional family and community, on one hand as well as the church on the other has resulted in some unofficial burial arrangements between the church and the families of the deceased. This was despite the church not officially subscribing to the indigenous beliefs and the practices. It was clear from the foregoing discourse that Traditional African culture to a large extent formed the subconscious mind of the African way of the ultimate knowing hence constituted the roots that Africans resort to in crisis moments such as death. It was thus apparent in this Interplay of the Church and indigenous culture that the Church finding itself in this uncomfortable position for lack of options easily accepted positions of cultural consonance without question as could be seen in the case with male dominance (patriarchy) as a Christian and Traditional African cultural feature of consonance as well. 
Patriarchy under African cultural ramification and the Church's omissions had transitioned to imply an institution of male rule and privilege entailing female subordination. In this institution, it would seem accurate to conclude that the husband constituted honor and dignity to womanhood, and the very moment a woman loses her husband; the woman automatically lost her prized dignity. Yet, from the Christian point of view, culture should never be used as a standard by which to measure scripture, instead, the Bible should be. It was in view of these observations that this study maintained that African Christians had been influenced by the traditional African widowhood rites. It was the same thesis that the current study sought to establish in the context of the Ababukusu traditional and Friends Church cultures with reference to widowhood rites and rituals.

Among the Ababukusu the woman was clearly at the center of the entire funeral rituals. The role of rituals in the provision of stability following the structural destabilization caused by death as a phenomenon among the Ababukusu people was also obvious. However, some of the rituals definitely presented difficult ordeals for the widow. The analysis of primary data in this study included that on the history of integration of the Ababukusu traditional and Friends Church widowhood rites and rituals; herein referred to as the Interplay. The analysis also examined the Ababukusu society from a gender perspective venturing into the consequences of the interplay for the widow with reference to the widowhood rites and rituals. The vulnerability of the widow to consequences of widowhood rites and rituals among the Ababukusu was finally analysed as it led to the conclusion of the chapter.

From the said analysis it was clear that abusive relationships abounded against women as the case of widowhood rituals among the Ababukusu including Christians confirmed in this study. Widowhood as a passage of life and its associated rites and rituals was found to be particularly fraught with danger for women when the trauma of losing one's partner was compounded by the societal and cultural expectations of widows in the face of a Church that was non-committal. The widowhood rites and rituals among the Ababukusu people, as this study confirmed, repositioned widows in society as objects of men's sexual desire and beings to be economically deprived. Consequently, Widows through widowhood rites and rituals were a disadvantaged group and prone to poverty and marginalization. As the Friends Church watched and even supported tacitly, as was the case in some instances, these rites and rituals subjected widows to patriarchal customs, discrimination on inheritance rights and isolation, psychological torture, and caused them to suffer abuse in the context of ritual cleansing and suspicion of infidelity and complicity in the demise of the spouse. All these took place in the context of a pact between traditional culture and the Church referred to in this study as the interplay.

\section{In Lieu of Contributions and Conclusion}

At the onset, the main problem of this study was to critically examine the interplay between the Ababukusu traditional and the Friends Church widowhood rites and rituals with special reference to the suffering to which they subjected African widows. In response, the study revisited and confirmed the point already mentioned that traditional African culture to a large extent formed the subconscious mind of the African way of the ultimate knowing hence constituted the roots to which Africans resorted to in crisis moments such as death. To this end, the Ababukusu traditional widowhood rites and rituals were supposed to have a positive effect of healing, as death still had a negative impact on the remaining person's lives. Widowhood rituals in this sense were supposed to have therapeutic value that assisted the bereaved in moving on with her life. Consequently, 
INTERNATIONAL JOURNAL OF ACADEMIC RESEARCH IN BUSINESS AND SOCIAL SCIENCES Vol. 10, No. 10, 2020, E-ISSN: 2222-6990 @ 2020 HRMARS

widowhood rites and rituals were supposedly patterned ways invented in traditional communities for the successful healing of the psychological wounds and pain of bereaved persons. Widowhood rites among the Ababukusu in particular and traditional Africa in general, it would appear, were therefore not primarily designed to de-womanize African womanhood, or impoverish and oppress women.

However, as already noted in regard to the interplay between the Ababukusu traditions and Friends church, the Church finding itself in an uncomfortable position for lack of options, easily accepted positions of cultural consonance uncritically. This could be seen in the case of male dominance (patriarchy) as both a Christian and Traditional African cultural feature of consonance. Yet, Patriarchy under African cultural ramifications and the Church's omissions has transitioned to imply an institution of male rule and privilege entailing female subordination and loss of dignity to womanhood particularly during crisis moments such as is presented by death. The primary data in this study showed that among the Ababukusu Christians with reference to the Friends Church, widowhood was a process characterized by rituals, forced remarriages, harassment, rejection, loneliness, poverty, loss of status, fear of the future and depression, and definitely with little or no therapy at all.

To revert to the main concern of this study, the main question of the study was; to examine the extent to which the combined Interplay of both the Ababukusu cultural and Friends church widowhood rites and rituals had subjugated the Ababukusu widow in Western Kenya? To this end, the study submits that even though Biblical teachings encouraged the Christian church to be compassionate towards widows and African practice of communalism encouraged the considerations of life giving values, the Ababukusu Friends Christian widows continued to be subjugated under widowhood rites and rituals. This research established in this regard that Ababukusu Friends Christians have been influenced by the indigenous widowhood rites and rituals that discriminated against and violated widows' human rights to the extent that they also shunned these care-seeking vulnerable women and discriminated against them.

\section{Recommendations}

The African value of communalism assumes a lot of significance here as it describes the capacity for reciprocity and dignity, humanity and mutuality in the interest of building and maintaining African communities with justice and mutual caring as argues Bekker (2010). The Bible on the other hand records the high value of widows to God the Father and God the Son in both the Old and New Testaments. The care of widows therefore is in part the true measure of justice amongst God's people as both testaments warn that any discriminatory and oppressive action against widows and orphans contravenes God's law relating to love. Ironically, it is the application of the true spirit of combined force of indigenous African values and the Christian church's compassion towards widows (which appear to be nonfunctional) that provides the best opportunity for embracing Ababukusu Christian widows in particular and African Christian widows in general out of their subjugation.

This however, may not entail blanket abandonment of these rites and rituals as may be the temptation, rather, the rites and rituals should be infused deliberately with more humane values as befits Ubuntu and Biblical teachings with regard to widowhood. This recommendation is informed by the fact that death in Africa is never conceived as an episode, but a process constituting of crisis moments in need of stabilization in a context where traditional African culture and not Christianity, forms the subconscious mind of the ultimate knowing. 
INTERNATIONAL JOURNAL OF ACADEMIC RESEARCH IN BUSINESS AND SOCIAL SCIENCES

Vol. 10, No. 10, 2020, E-ISSN: 2222-6990 @ 2020 HRMARS

\section{References}

Bayly, J. (1978) Last Thing We Talk About, London: Scripture Union Publishers.

Bekker, H. F. ( 2010) https://doi.org/10.1017/CB09780511675881.

Durkheim, E. (1965) Elementary Forms of Religion. New York: Free Press.

Kanstebaum, R. (2003) https //doi.org/10.1177/105413730238955.

Manala, M. (2015), "African traditional widowhood rites and their benefits and/or detrimental effects on widows in a context of African Christianity," Herv. Teol study. vol.71 n.3 Pretoria.

Mawson, A. R. (2005) Belief in God. An Introduction to the Philosophy of Religion. T.J. Publication ISBN 9780199284955.

Mbiti, J. S. (1969) African Religions and Philosophy. London: Heinemann Educational books Ltd.

Opuku, K. A. (1978) West African Traditional Religion. Lagos FEP.

Schopenhauer, A. (2010) The world as will and representation Vol 1. Paraliphomena: Cambridge University Press. 